\title{
BAtIASA DAN IDENTITAS BUDAYA
}

\author{
Budi Santoso Universitas Dian \\ Nuswantoro
}

\begin{abstract}
Language is an arbitrary system of sound used by members of a social group to cooperate, communicate, and identify one self. The paper discusses the use of language to identify personal identity, social class, ethnicity, and nationality. Language can determine the identity of an individual and a group. Language is also used to identify or to show the personal identity of a person. Furthermore, language shows the social class of a person. A person who comes from the low level class has a different language style from those of the higher level class. As ethnic identity, language can be used to denote ethnicity or the membership of a person or group in a certain ethnic group. Language can also become the national identity as well. Thus, every country has its own national language.
\end{abstract}

Key Words: language, self identification, social identity, ethnic identity, and national identity.

\section{Pendahuluan}

Sebagai makhluk sosial, mahusia akan selalu berhubungan dan bekerja sama dengan manusia lain. Setiap orang membutuhkan keberadaan orang lain untuk memenuhi berbagai macam kebutuhannya. Dalam hubungan antara individu dengan individu lainnya diperlukan suatu sarana untuk berkomunikasi, yaitu bahasa. Menurut Djoko Kenjono (dalam Chaer, 2003: 30), bahasa merupakan sistem lambang bunyi yang arbitrer yang digunakan oleh anggota kelompok sosial untuk bekerja sama, berkomunikasi, dan mengidentitikasikan diri. Bahasa tidak hanya sekedar sistem bunyi, morfologis, dan sintaktis yang dirancang untuk menyatakan suatu pikiran, tetapi juga membawa identitas budaya dan status sosial. Bahasa mencerminkan kondisi sosial dan hubungan antarmanusia (Paulston, 1986: 116).

Definisi bahasa di atas mengandung makna bahwa bahasa tidak hanya digunakan sebagai alat komunikasi dan bekerja sama, tetapi juga berfungsi sebagai alat untuk mengidentitikasikan diri suatu kelompok sosial. Melalui bahasa dapat diketahui identitas individu atau kelompok sosial. Oleh karena keberadaan bahasa dalam suatu komunitas sangat penting. maka ia dijadikan sebagai salah satu unsur kebudayaan (Koentjaraningrat, 1974). Sebagai unsur suatu budaya, bahasa mempunyai hubungan erat dengan identitas suatu budaya. Tulisan ini membahas bagaimana bahasa digunakan untuk mengidentifikasi identitas personal, kelas sosial, etnis, dan nasional.

\section{Identitas Budaya}

Identitas mengacu pada karakter khusus individu atau anggota suatu kelompok atau kategori sosial tertentu. Identitas berasal dari kata "idem" dalam bahasa Latin yang berarti sama. Dengan demikian identitas mengandung makna kesamaan atau kesatuan dengan yang lain dalam suatu wilayah atau hal-hal tertentu (Rummens, 1993:157-159), Selain mengandung makna kesamaan, identitas juga mengandung makna perbedaan. Identitas dapat juga bermakna suatu karakter yang membedakan suatu individu atau kelompok dari individu atau kelompok lainnya. Dengan demikian identitas mengandung dua makna, yaitu hubungan persamaan dan hubungan perbedaan. Hubungan persamaan dalam identitas muncul ketika suatu individu mempunyai kesamaan dengan individu lain dalam suatu kelompok. Hubungan perbedaan dalam identitas muncul 
Sahda, Volume I, Nomor 1, September 2006: M - 49 ketika suatu individu atau kelompok mempunyai suatu karakter tertentu yang membedakan individu atau kelompok tersebut dari individu atau kelompok lainnya.

Identitas yang dimiliki oleh seorang individui dapat berupa identitas personal (persona/ identity) dan identitas sosial (soc/a/ identity). Identitas personal merupakan hasil dari suatu identifikasi diri, oleh dirinya sendiri, dengan penilaian dari orang lain. Identitas personal merupakan suatu karakter tertentu yang dimiliki oleh seorang individu yang membedakan dari orang lain. Identitas personal dapat berupa ciri-ciri fisik seperti wajah dan tinggi badan, atau ciri psikologis seperti sifat, tingkah laku, dan gaya bicara. Identitas sosial merupakan hasil dari identifikasi diri oleh orang lain, dan merupakan suatu identifikasi yang disetujui atau diberikan seorang pelaku sosial (social actor) kepada seorang individu (Rummens, 1993). Secara lebih jelas, identitas sosial merupakan suatu pengetahuan dan pengakuan diri individu sebagai anggota suatu kelompok serta pengakuan kelompok kepada individu tersebut sebagai anggotanya (Giles dan Johnson, 1987).

Identitas sosial dapat meliputi antara lain religi, etnis (suku bangsa), dan kelas sosial. Identitas etnis merupakan identifikasi individual dengan unit sosial yang anggotanya mempunyai asal-usul bersama dan berbagi unsur budaya yang sama dan mereka berpartisipasi dalam kegiatan-kegiatan yang didasarkan pada unsur budaya dan asal-usul bersama (Yinger, 1976:

200). Identitas etnis akan muncul pada masyarakat yang kompleks, misalnya masyarakat dengan aparatur negara dan kelas sosial yang berfungsi membagi masyarakat dalam berbagai kategori. Identitas-identitas yang terdapat dalam identitas sosial tersebut berkaitan erat dengan identitas budaya, karena merupakan cakupan dari identitas budaya.

Identitas budaya merupakan kesadaran dasar terhadap karakteristik khusus kelompok yang dimiliki seseorang dalam hal kebiasaan hidup, adat, bahasa, dan nilai-nilai (Dorais, 1988). Identitas etnis berhubungan erat dengan identitas budaya, karena untuk mengategorikan suatu masyarakat, seseorang harus mengetahui ciri khas budaya mereka, atau dengan kata lain identitas etnis dapat menunjukkan identitas budaya suatu kelompok. Identitas etnis pada umumnya berkaitan erat dengan budaya, politik, dan ekonomi. Identitas ini mempunyai hubungan yang kuat dengan politik yang didefinisikan sebagai kekuatan untuk mengontrol dan mengatur distribusi dan ketersediaan sumbersumber daya.

Selain identitas personal dan identitas sosial, terdapat suatu identitas berdasarkan wilayah yang disebut dengan identitas regional. Identitas regional didasarkan pada batas-batas wilayah suatu kelompok atau komunitas, dan dalam wilayah yang lebih besar dapat menjadi identitas nasional. Identitas regional dan identitas nasional berkaitan erat dengan sistem politik suatu wilayah atau negara.

\section{Bahasa dan Identitas Budaya}

Seperti telah dijelaskan pada bagian sebelumnya, bahasa digunakan sebagai sarana untuk mengidentifikasi diri. Dengan bahasa dapat diketahui identitas individu dan kelompok. Bahasa dapat digunakan untuk mengidentifikasi atau menunjukkan identitas personal seseorang, karena ketika seseorang berbicara dapat diketahui jenis ketamin, usia (anak-anak, dewasa atau orang lanjut usia), dan siapakah individu tersebut. Hal ini disebabkan ofeh setiap individu mempunyai ciri khas tertentu ketika berbicara.

Gaya berbicara yang dimiliki individu dan menjadi ciri khasnya disebut dengan ideoiek (Malmkjear, 1991: 344). Ketika seseorang berbicara, kita akan tahu apakah ia seorang perempuan atau laki-laki, karena suara perempuan berbeda dari suara laki-laki, Selain itu, juga akan dapat diketahui usia penutur tersebut, apakah anak-anak, orang dewasa, atau orang lanjut usia. Sebagai contoh adalah ketika kita sedang berada di dalam kamar dan kemudian kita mendengar ayah bercakap-cakap dengan temannya di luar kamar. Pada saat salah seorang dari mereka berbicara, kita akan mengetahui siapakah yang sedang berbicara, 
Sdbda, Volume // Nomor L September 2006: $M$ - 49 ayah ataukah temannya, meskipun kita tidak melihatnya. Dari gaya berbahasanya, kita dapat mengetahui identitas penuturnya, karena kita dapat membedakan gaya berbahasa ayah dengan gaya berbahasa temannya.

Pemilihan kata dalam berbahasa juga dapat digunakan untuk mengidentifikasi identitas seseorang. Pada masa pemerintah Orde Baru, misalnya, ketika sedang nnendengarkan cuplikan pidato pejabat negara dalam suatu siaran berita di radio, kita dapat mendengarkan seorang pejabat negara mengucapkan kata "diamanken". Begitu mendengar kata "diamanken", akan segera diketahui identitas penjabat tersebut, yaitu Presiden Soeharto. Hal ini karena pejabat tersebut sering mengucapkan kata itu dalam pidatonya dan kemudian menjadi karakter yang membedakan dirinya dari orang lain, karena orang lain akan mengatakan "diamankan", bukan "diamanken".

Sebagai identitas sosial, bahasa dapat digunakan untuk menunjukkan kelas sosial seseorang. Seseorang yang berasal dari kelas sosial rendah mempunyai gaya berbahasa yang berbeda dari orang yang berasal dari kelas sosial lebih tinggi. Gaya berbahasa orang yang terdidik juga berbeda dari gaya berbahasa orang yang kurang terdidik. Hal ini menjelaskan bahwa dalam suatu komunitas terdapat suatu variasi bahasa antara individu yang berstatus sosial rendah dan yang berstatus sosial lebih tinggi.

Variasi bahasa yang didasarkan pada perbedaan status sosial disebut dengan diaiek sosial atau sosioiek (Wardhaugh, 1988: 46). Sebagai contoh, dalam masyarakat Inggris pada 1950-an terdapat kata dengan pengertian yang sama dapat digunakan untuk membedakan kelas sosial penuturnya. Masyarakat Inggris kelas atas menggunakan kata sitting room dan lavatory, sedangkan masyarakat kelas bawah menggunakan kata lounge dan toilet. Variasi bahasa yang sama juga terjadi dalam masyarakat India. Bahasa yang digunakan oleh kasta Brahmana berbeda dari bahasa kasta bukan Brahmana. Untuk menyebutkan kata "susu", misalnya, anggota kasta Brahmana menggunakan kata "haalu", sedangkan anggota kasta bukan Brahmana menggunakan kata "aalif'. Para Brahmana di wilayah Tamil menggunakan kata "tuung $U^{\prime}$ untuk menyatakan tidur, sedangkan kasta bukan Brahmana menggunakan kata "orange (Wardhaugh, 1988:46-47). .

Sebagai indentitas etnis, bahasa dapat digunakan untuk menunjukkan etnis atau keanggotaan seseorang atau suatu kelompok dalam suatu suku bangsa tertentu. Di Indonesia terdapat berbagai macam suku bangsa antara lain Jawa, Sunda, Madura, Bugis, dan Batak. Masing-masing suku bangsa tersebut mempunyai bahasa yang menjadi ciri khas mereka. Suku Sunda, Jawa, dan Madura meskipun berada dalam satu pulau, tetapi karena bahasanya berbeda. maka disebut sebagai suku-suku yang berbeda. Sebaliknya sebuah kelompok masyarakat walaupun tidak berada dalam satu wilayah, tetapi mempunyai bahasa yang sama, akan disebut sebagai satu suku. Di wilayah Provinsi Lampung di Pulau Sumatera, misalnya, terdapat satu daerah yang bernama Kampung Jawa. Masyarakat di wilayah tersebut dikenal dengan nama Japung, singkatan dari Jawa Lampung. Masyarakat di Kampung Jawa tersebut menggunakan bahasa Jawa dalam berkomunikasi sehari-hari, sehingga mereka dianggap sebagai masyarakat suku Jawa meskipun tidak tinggal di pulau Jawa.

Hal serupa juga dapat ditemukan pada kelompok masyarakat kesukuan yang ada di ibukota Jakarta. Mereka tinggal bersama dalam satu wilayah dan komunitas yang sama dengan suku mereka dan berkomunikasi dengan bahasa suku mereka masing-masing. Oleh karena itu, di Jakarta terdapat Kampung Bali, Kampung Ambon, Kampung Madura, dan Kampung Bugis. Kesukuan mereka pada dasarnya ditentukan oleh wilayah asal mereka, tetapi hal yang paling cepat digunakan untuk mengidentifikasikan identitas etnis mereka adalah bahasa yang mereka gunakan. Misalnya saja, ketika sedang berjalan-jalan, kita 
Sahda, Volume I, Nomor 1, September 2006: 44 - 49 mendengar sekelompok orang berbicara dafam bahasa Madura. Kita dengan cepat akan dapat menduga bahwa mereka berasal dari suku Madura. Contoh lainnya adalah ketika kita mendengar seorang mengucapkan kata "kenapa" dengan bunyi [kenapa], maka identitas etnis orang tersebut akan dapat segera diketahui, yaitu suku Batak, karena dalam Bahasa Batak tidak terdapat bunyi Id, yang ada bunyi /e/. Etnis selain Batak mengucapkan [kenapa], bukan [kenapa].

Pada masyarakat Cina, identitas etnis dapat dijumpai di daerah Pecinan di berbagai wilayah. Akan tetapi, identitas tersebut biasanya lebih dilihat sebagai identitas ras (rac/'a/ identity) daripada identitas etnis [ethnic identity). Sebagian besar orang melihat mereka yang berkulit kuning dan bermata sipit sebagai orang Cina. Ini merupakan identifikasi identitas berdasarkan ciriciri fisik dari seorang individu yang cenderung mengarah pada identitas ras. Apabila dilihat lebih cermat, masyarakat Cina yang tinggal di berbagai Pecinan di seluruh dunia tidak berasal dari satu suku. Mereka berasal dari berbagai macam suku yang ada di Cina seperti suku Hokkian, Kanton, dan Hakka.

Kekeliruan mengidentifikasi identitas etnis tersebut disebabkan oleh ketidaktahuan sebagian besar orang tentang suku-suku yang ada di Cina serta adanya anggapan bahwa bahasa yang mereka gunakan sama. Di sini terlihat bahwa bahasa berperan penting dalam menentukan identitas etnis suatu kelompok. Anggapan bahwa mereka itu etnis Cina muncul, karena bahasa yang mereka gunakan terdengar mirip. Hal ini terjadi, karena bahasa-bahasa yang mereka gunakan berasal dari rumpun bahasa yang sama, yaitu bahasa Han Tai \{Kamus Besar MandarinIndonesia, 1998:

XLVI). Meskipun bahasa-bahasa tersebut berasal dari rumpun yang sama, tetapi merupakan bahasa yang berbeda, karena di antara pemakainya tidak dapat saling berkomunikasi. Perbedaan bahasa ini juga menunjukkan adanya perbedaan identitas etnis dalam masyarakat Cina.
Keberadaan bahasa Hokkian, Kanton, Hakka, dan yang lainnya sangat penting dalam pengidentitfikasian identitas masyarakat Cina. Masyarakat Hokkian akan menggunakan bahasa Hokkian ketika berbicara dengan sesama anggota suku Hokkian. Masyarakat suku Kanton juga akan menggunakan bahasa Kanton saat berbicara dengan sesama anggota sukunya, dan demikian juga masyarakat Hakka yang akan berbicara bahasa Hakka dengan sesama anggota suku Hakka. Perbedaan bahasa suku Hokkian, Hakka, dan Kanton menandakan adanya perbedaan suku dalam masyarakat Cina yang juga menandakan adanya perbedaan budaya di antara suku-suku tersebut. Dengan demikian malalui perbedaan bahasa dalam masyarakat Cina dapat diketahui identitas suku sekaligus budayanya.

Bahasa juga dapat digunakan sebagai identitas regional. Masyarakat dari tempat yang berbeda biasanya berbicara dalam aksen yang berbeda, sekalipun mereka menggunakan bahasa yang sama. Variasi bahasa yang muncul karena perbedaan tempat atau wilayah disebut dengan diaiek regional (Wardhaugh, 1988: 40). Contoh yang sering ditemui adalah perbedaan bahasa Jawa yang digunakan oleh penutur bahasa Jawa dari wilayah Banyumas dan wilayah di luar Banyumas. Penutur bahasa Jawa dari diaiek Banyumas biasanya menambahkan bunyi /k/ dalam suatu kata dan bunyi [a] dibaca /a/. Para penutur bahasa Jawa di wilayah luar Banyumas tidak menambahkan bunyi /k/ dalam suatu kata dan membaca bunyi [a] sebagai /u/. Misalnya dalam kata "apa" yang berarti "apa", penutur diaiek Banyumas akan mengatakan [hapa/], sedangkan penutur dari wilayah luar Banyumas akan mengatakan [hupu], Ketika seseorang berbicara dan mengatakan [hapa/], maka akan segera diketahui bahwa orang tersebut berasal dari wilayah Banyumas dan sekitarnya.

Pada batas wilayah yang lebih besar, bahasa dapat digunakan sebagai identitas nasional. Setiap negara mempunyai bahasa masingmasing yang digunakan sebagai bahasa nasionat. Bahasa nasional merupakan 
5obc/o/ Volume I, Nomor 1, September 2006:44 - 49 bahasa dalam unit potitik, sosial, dan budaya. Pada umumnya bahasa nasional digunakan sebagai simbol persatuan bangsa. Bahasa nasional beriungsi sebagai alat identitas bangsa dan alat pemersatu masyarakat (Holmes, 2001: 97).

Penggunaan bahasa sebagai identitas nasional erat hubungannya dengan politik suatu negara. Sebagai contoh adalah bahasa nasional Malaysia, yaitu bahasa Melayu dan bahasa Indonesia. Pada dasarnya kedua bahasa tersebut bukanlah bahasa yang berbeda, salah satunya hanya merupakan variasi dari bahasa lainnya. Akan tetapi, karena adanya perbedaan wilayah dan politik, yaitu bahwa Malaysia dan Indonesia adalah dua negara yang berbeda, maka kedua bahasa tersebut kemudian menjadi dua bahasa yang berbeda. Pemerintah Malaysia menyatakan bahwa bahasa nasional mereka adalah bahasa Melayu, bukan bahasa Indonesia; sedangkan pemerintah Indonesia menyatakan bahwa bahasa nasional mereka adalah bahasa Indonesia, bukan bahasa Melayu, meskipun pada dasarnya kedua bahasa tersebut adalah bahasa yang sama.

Peristiwa yang sama juga terjadi pada bahasa Cina. Orang Taiwan menyebut bahasa nasional mereka Guoyu, sedangkan orang Repubtik Rakyat Cina (RRC) menyebutkan bahasa nasional mereka Putonghua. Bahasa Guoyu dan bahasa Putonghua adalah bahasa yang sama. Sekalipun demikian, karena masalah kepentingan politik, masing-masing negara memberikan nama berbeda. Kedua bahasa tersebut tidaklah sepenuhnya sama, karena terjadi berbagai penyederhanaan aksara dalam bahasa Putonghua, sedangkan dalam Guoyu tidak terjadi penyederhanaan aksara. Akan tetapi, hal ini tidak membuat kedua bahasa tersebut menjadi bahasa yang berbeda, karena antara kedua bahasa tersebut dapat terjalin komunikasi.

Pengaruh politik dalam bahasa Cina baik Guoyu maupun Putonghua tampak jelas jika dilihat dari sejarahnya. Sebelumnya $R R C$ berdiri, masyarakat Cina sudah mengunakan bahasa Mandarin. Pada saat itu Cina diperintah oleh partai Nasionalis. Dalam perkembangan sejarah selanjutnya, terjadi perseteruan antara partai Komunis dan partai Nasionalis, yang akhirnya dimenangkan oleh partai Komunis. Pihak partai Nasionalis yang kalah melarikan diri ke kepulauan Formosa (Taiwan), sedangkan pihak partai Komunis mendirikan negara Republik Rakyat Cina pada tahun 1949.

Di wilayah kepulauan Formosa, Partai Nasional mendirikan negara Republik Cina. Mereka kemudian menetapkan bahasa Mandarin sebagai bahasa nasional dengan nama Guoyu tanpa adanya penyederhanaan huruf dan tetap menggunakan huruf kompleks (Fantizf). Di wilayah Cina Daratan. pemerintah RRC kemudian menetapkan bahasa Mandarin sebagai bahasa nasional dengan nama Putonghua. Dalam penetapan bahasa nasional tersebut, juga diadakan suatu penyederhanaan terhadap hurufhuruf yang dianggap rumit yang kemudian disebut dengan nama huruf sederhana (Jiantizf). Sampai saat sekarang, semua dokumen atau pun tulisan yang berasal dari Taiwan menggunakan huruf kompleks \{Fantizi) sebagai identitas mereka, sedangkan masyarakat RRC menggunakan huruf sederhana (Jiantizi) sebagai identitas nasional $\mathrm{RRC}$.

\section{Simpulan}

Salah satu fungsi bahasa adalah untuk mengidentifikasi suatu kelompok. Ini berarti dengan bahasa dapat diketahui identitas seorang baik individu maupun ketompok. Bahasa dapat digunakan untuk menunjukkan identitas personal seseorang, karena setiap individu mempunyai gaya berbahasa yang berbeda dari orang lain. Sebagai sarana identitikasi identitas kelompok, bahasa yang digunakan oleh suatu kelompok dapat menunjukkan status sosia! atau pun kesukuan kelompok tersebut. Bahasa dapat digunakan 
Identitas nasional dan identitas regional juga dapat diidentifikasi melalui bahasa.

sebagai alat identitas status sosial, karena masyarakat dengart status sosial yang tinggi mempunyai gaya bahasa yang berbeda dari masyarakat dengan status sosial rendah. Bahasa juga dapat digunakan sebagai sarana mengidentifikasi kesukuan atau etnis, karena setiap etnis biasanya mempunyai bahasa masing-masing yang berbeda dari etnis lainnya. Hal ini berkaitan dengan identitas budaya, karena untuk mengategorikan etnis harus memahami unsur budaya yang ada dalam masyarakat, dalam hal ini adalah bahasa.

Masyarakat dari daerah yang berbeda mempunyai cara pengucapan dan bunyi bahasa yang berbeda meskipun bahasa yang digunakan sama. Selain itu, dalam skala teritorial yang lebih luas, bahasa dapat digunakan untuk menunjukkan identitas kebangsaan suatu masyarakat. Dalam hal ini bahasa digunakan sebagai alat identitas bangsa dan sekaligus pemersatu bangsa.

\section{DAFTAR PUSTAKA}

Chaer. Abdul. 2003. Linguistik Umum. Jakarta: Rineka Cipta. Dorais, Louis Jacques.

1988. "Intoit Identity in Canada", dalam Folk. Vol. 30. him. 23-31.

Giles, H. and P. Johnson. 1987. "Ethnolinguistic Identity Theory: A Social Psychological Approach to Language Maintenance", dalam The International Journal of the Sociology Language. Vol. 68, him. 69-99.

Holmes, Janet. 2001. An Introduction to Sociolinguistics. London: Longman Group UK Limited.

Koentjaraningrat. 1984. Kebudayaan, Mentalitas, dan PembangunQn. Jakarta: Gramedia.

Malmkjaer, Kirsten. 1995. The Linguistics Encyclopedia. New York: Routledge.

Paulston, C,B.. 1986. "Linguistic Consequences of Ethnicity and Nationality", dalam Language and Education in Multi-Lingual Setting (editor B. Spolsky). San Diego: College-Hill Press.

Rummens J.. 1993. "Personal Identity and Social Structure in Saint Maartin: A Plural Identity Approach". Unpublished Thesis/Dissertation, York University.

Tim Perkamusan Universitas Indonesia. 1998. Kamus Besar Mandarin-Indonesia. Jakarta : UI Press.

Wardaugh, Ronald, 1988. An Introduction to Sociolinguistics. New York: Basil Blackwell Ltd..

Yinger, J. M- 1976. "Ethnicity in Complex Societes". dalam The Use of Controversy in Sociology. (editor L. A. Coser dan 0. N. Larsen). New York: Free Press. 